\title{
OBSERVATION OF DISTRIBUTION AND QUALITATIVE PROPERTIES OF HORSELIVESTOCK (EQUUSCABALLUS) IN NORTH SUMATRA)
}

\author{
A Gultom, Hamdan, M Tafsin, S Umar, and AH Daulay \\ Animal Production Study Program, Faculty of Agriculture, University of Sumatera \\ Utara, Medan 20155 \\ E-mail : jpi@usu.ac.id
}

\begin{abstract}
This study aims to determine the spread of horses and horses based on the observation of the color of feathers, facial marks, foot shape and back shape in Humbang Hasundutan, Samosir, Karo and North Tapanuli districts. This research was conducted in July-September 2016 by performing phenotypic analysis (color and face mark) at 271 horses in Humbang Hasundutan District, Samosir Regency, Karo Regency and North Tapanuli Regency. The research method used is survey method and Simple Random Sampling method (simple random sampling) done to determine the cattle that will be used as sample.

The analysis shows that horses in North Sumatera have various color and dominant red brown $(27,86 \%)$. Horses in North Sumatra have various dominant faces that dominate strike $(54.95 \%)$.

Keywords : distribution, qualitative, horselivestock
\end{abstract}

\section{Introduction}

Horses are one of the animals that have been kept since ancient times. Horses since ancient times used as a means of human transportation and used as a mount when hunting. Today's horses are used as racehorses, sport horses, horse mounts, delman horses and protein food sources. The horse population in Indonesia is around 400,000 heads spread in some areas. However, the number of horses in North Sumatra, especially in Humbang Hasundutan (525), Samosir (455), Karo (151) and North Tapanuli (126).

The qualitative nature of horsehair is a genetically inherited external trait. The genes that control the color of the horse are divided into several, resulting in the color of bay, black, chestnut, bay-cream, chestnut-cream, roan, spotted and white. Such properties have appeal to breeders and scientists so that information on horse colors is found in many horse lovers associations. Common feather colors are used to identify the horse race. Certain horse nuns have feather color as a characteristic genetic characteristic.

Genetic information about the qualitative characteristics of local horse in Indonesia, especially in North Sumatra, is still very limited. On this basis it is necessary to conduct research on the qualitative nature of local horsehair patterns in North Sumatra, especially in Humbang Hasundutan, Samosir, Karo and North Tapanuli districts. 


\section{Materials and Methods}

This research was conducted from July to September 2016 located in Humbang Hasundutan, Samosir, Karo and North Tapanuli regencies, North Sumatera because the 4 districts have the largest horse population in North Sumatera

The materials used are adult males and adult bodies as many as 231 heads (Karo District as many as 60 heads, Humbang Hasudutan District as many as 77 heads, North Tapanuli Regency as many as 52 heads and Samosir regency of 42 tails).

Tools used in this panelitian are stationery, cameras and interview sheets (questionnaires) that have been prepared previously.

The research method used is survey method. The technique for determining the livestock used in simple random sampling is a probability sampling type, in which the researcher chooses samples by giving equal opportunity to all members of the population who have mature and adult bodies to be defined as sample members. The data were processed using descriptive analysis: color and face sign (Sudjana, 2002).

\subsection{Parameters observed}

\section{Qualitative nature}

1. Color

Observations made by looking at the physical properties that appear based on the fur color is classified into 3, namely: black, chesnut and gray.

- Black (bay): Horses with bay colors are horses that have manes, tail and colored legs black. The base color of the bay consists of three kinds of bright bay or light bay ie reddish brown or brown; bright bay or bright bay is the color of chesnut and dark bay or dark bay that tend to be dark brown (Brown and Sarah, 1994).

- Chesnut: Chesnut is a reddish brown on feathers and also the color of the tail and mane (Vogel, 1995). Chesnut is part of the red pigment, as found on horses colored sorrel, palomino and red duns.

- Gray: The gray color on the horse can be found on the pony type up to the heavy horse. Gray horses have colors ranging from white to dark gray with age.

2. Face marks

Observations made by looking at the marks on the faces of cattle were observed (Snipe, Blaze, Stripe, Bald Face and Star).

- Snipe: Snipe the white mark is only in the nose.

- Blaze: Blaze the same white mark as the Stripe but the line is wider than the Stripe line.

- Stripe: Stripe has a white mark on the face like a small line from the forehead to the nose.

- White Face: White signs of white face type have white marks all over the horse's face.

- Star: a white mark on a face that has a white patch like a star

Data analysis Analysis of observed horse phenotype observation data is presented in the form of drawings. Each horse has complete information about the phenotype. Each horse drawing is given an identity number. The phenotype frequency of each feather color observed on each horse type was calculated using the Minkema method (1993):

$$
\text { Phenotype Frequency }=\frac{\text { Number of Individual Horses with a Particular Phenotype }}{\text { Total Individal Horses Obsereved }}
$$

\section{Results and Discussion}

The results of the research on the diversity of horse color and the sign of the face on the horse then performed the recapitulation of research results can be seen in the table below. 
Table 1. Diversity of horse color $(\%)$

\begin{tabular}{|c|c|c|c|c|c|c|c|c|}
\hline \multirow{3}{*}{ District } & \multicolumn{7}{|c|}{ Color $(\%)$} & \\
\hline & \multicolumn{3}{|c|}{ Black } & \multicolumn{3}{|c|}{ Brown } & \multicolumn{2}{|l|}{ Grey } \\
\hline & $\mathrm{Me}$ & $\mathrm{Ce}$ & $\mathrm{Ge}$ & $\mathrm{Me}$ & $\mathrm{Ku}$ & $\mathrm{Pu}$ & $\mathrm{Aa}$ & $\mathrm{Pt}$ \\
\hline Karo & 15,00 & 3,33 & 13,33 & 38,33 & 3,33 & 10,00 & 3,33 & 13,33 \\
\hline Humbahas & 10,39 & 9.09 & 11,69 & 33,77 & 9,09 & 9,09 & 10,39 & 6,49 \\
\hline Taput & 19,23 & 7,69 & 9,62 & 30,77 & 3,85 & 11,54 & 7,69 & 9,62 \\
\hline Samosir & 14,29 & 11,90 & 14,29 & 19,05 & 14,29 & 11,90 & 7,14 & 7,14 \\
\hline Total & 58,91 & 22,92 & 48,93 & 121,92 & 30,56 & 42,53 & 28,55 & 36,58 \\
\hline$\overline{\text { Mean }}$ & 14,73 & 7,64 & 12,23 & 30,48 & 7,64 & 10,63 & 7,14 & 9,15 \\
\hline
\end{tabular}

Describtion: $\mathrm{Me}=$ Red, $\mathrm{Ce}=$ Bright, $\mathrm{Ge}=$ Dark, $\mathrm{Ku}=$ Yellow, $\mathrm{Pu}=$ Faded, $\mathrm{Aa}=$ Grey dan $\mathrm{Pt}=$ White

Table 2. Diversity of facial markings (\%)

\begin{tabular}{llllll}
\hline \multirow{2}{*}{ District } & \multicolumn{5}{c}{ Facial Markings (\%) } \\
\cline { 2 - 6 } & Snipe & Blaze & Strike & White & Star \\
& & & & Face & \\
\hline Karo & 10,00 & 5,00 & 53,33 & 16,67 & 15,00 \\
Humbahas & 6,49 & 10,39 & 55,84 & 11,69 & 15,58 \\
Taput & 25,00 & 9,62 & 48,08 & 11,54 & 5,77 \\
Samosir & 4,76 & 11,90 & 59,52 & 7,14 & 16,67 \\
\hline Total & 46,25 & 36,61 & 216,77 & 47,04 & 53,02 \\
\hline Mean & 11,56 & 9,23 & 54,19 & 11,76 & 13,26 \\
\hline
\end{tabular}

\subsection{Horse Color Diversity}

The results showed that the variation of horse color in Karo Regency is chesnut (brown) red (38.33\%) followed by consecutive black, red (15.00\%), dark black and gray puti (13.33\%), faded brown $(10.00 \%)$ and followed by bright black, yellow brown and gey ash -abu (3.33\%). The color of the horse classified into black is black red, bright black and dark black of $31.67 \%$, while the chesnut color is red, yellow, fading of $51.67 \%$ of the overall population of the study sample and $16.67 \%$ of the horse in Karo District shows the color that gray is gray and white. This is in accordance with the statement Vogel [1] which states that chesnut is a reddish-brown color on the fur and which also becomes the color on the tail and mane. Black pigments that control the properties of black, brown and bay are dominant in the red pigment. Chesnut is part of the red pigment, as found on horses colored sorrel, palomino and red duns. Described by Bowling and Ruvinsky (2000) that the chestnut color is controlled by the Extension (E) locus which can be occupied by two alleles, E for eumelanin and e properties for phaeomelanin properties.

The results showed that the variation of horse color in Humbang Hasundutan Regency was red chocolate of $33.77 \%$ followed by dark dark (11.69\%), black red and gray (10.39\%), bright black, brown yellow and brown faded (9.09) and white (6.49\%). The color of the horse which is classified 
into black color is black red, black and dark black with $31,17 \%$, while chesnut color is red, yellow, fading equal to $51,95 \%$ from whole population of research sample and $16,88 \%$ from horses in Humbang Hasundutan district show the color that gray is gray and white. This is in line with Bowling's and Ruvinsky's (2000) statements which suggest that the horse's body color follows the behavior of genes for qualitative properties in which red (chestnut) is recessive to black (black) controlled by red genes, paired with other genes for forming another variation of whether the totol or gray. The basic color of the horse is chestnut, bay, brown and black, and modified because there are other genes that control so that the colors appear: black, darkbay, lightbay, liverchestnut, chesnut, dun, strawberry roan The white color of the legs will be categorized as follows: the white color of the nail to the knee length (long sock), lower than the knee (the color of the nails) short sock), only in the area of the foot joint (white pastern), lower again (short white pastern) and only sestrip above the nail (coronet).

The results showed that the variation of horse color in North Tapanuli Regency was red chocolate of $30.77 \%$ followed by red black $(19.23 \%)$, dark black and white $(9,62 \%)$, bright gray and black (7.69\%) and yellow chocolate $(3.85 \%)$. The color of the horse that is classified into black color is black red, bright black and dark black by $36.54 \%$, while the color of chesnut is red, yellow, fading of $46.15 \%$ of the overall population of the study sample and $17.31 \%$ horses in North Tapanuli Regency showed the gray and white colors. This is in accordance with the statement of Brown and Sarah (1994), which states that the horse with the color of the bay is a horse that has a mane, tail and feet are black. The base color of the bay consists of three kinds of bright bay or light bay ie reddish brown or brown; bright bay or bright bay is the color chesnut and dark bay or dark bay which tend to be dark brown. According Bowlingand Ruvinsky (2000), bay is a black pigment that spreads and forms a pattern on the mane, tail and legs on the knee down. The focus that governs this color is agouti. The color of the bay or black is controlled by the agouti (A) loci which can be occupied by two alleles A for bay properties and a for black properties.

The results showed that the variation of horse color in Samosir Regency was red chocolate of $19.05 \%$ followed by red, dark black and yellow brown (14.29\%), bright black and faded brown (11.90\%), and gray and white $(7.14 \%)$. The color of the horse which is classified into black color is black red, bright black and dark black is $40.48 \%$, while the color of chesnut is red, yellow, fade of $45.24 \%$ from the whole population of research sample and 14,29\% from horses in Samosir District show the color gray is gray and white. This is in accordance with the statement of Edwards [2] states that local Indonesian horses (including horse Sumba) are classified into ponies. Roberts [3], states that all ponies (including Sumbanese horses in it) have adapted physically and changed their lifestyles to survive the conditions in which they live. Type of local Indonesian horses include KudaKuda Priangan, Javanese Horse, Padang Horse and Batak Horse.

\subsection{Diversity of Horse Face Signs}

The results showed that the variation of facial markings in Karo Regency were stripe $(53.33 \%)$ followed by white face $(16,67 \%)$, star $(15,00 \%)$, snipe $(10,00 \%)$ and blaze $(5.00 \%)$. This is consistent with the statement of Bowling and Ruvinsky [4] which states that horses have a variety of colors and have a special sign, usually horses are distinguished from color before discrimination of the nation or gender. Horses of the same color can be distinguished from those another with white markings forming different patterns may be white stripe on the forehead, rather wide-white (blaze), almost extending over the nose and around the eye (white face) or just shaped like a star on the forehead (star) and on the snout between the two nostrils (snip).

The results showed that variation of facial sign in Humbang Hasundutan regency was stripe $(55,84 \%)$ followed by star $(15,58 \%)$, white face $(11,69 \%)$, blaze $(10,39 \%)$ and snipe $(6.49 \%)$. This is consistent with the statement of Noor (2008) which states that genetically the horse's body color follows the behavior of genes for qualitative properties in which red (chestnut) is recessive to black (black) controlled by red genes, paired with other genes to form variations whether it is totol, or gray. The basic color of the horse is chestnut, bay, brown and black, and modified because there are other 
genes that control so that the colors appear: black, darkbay, lightbay, liverchestnut, chesnut, dun, strawberry roan, palomin, bald pie, skewbald, odd-colourd, blue roan, dapple gray, fleabitten gray, gray and albino.

The results showed that variation of facial markings in Tapanuli Utara District were stripe $(48,08 \%)$ followed by snipe $(25,00 \%)$, white face $(11,54 \%)$, blaze $(9,62 \%)$ and Star $(5.77 \%)$. This is in accordance with the statement of Eckstrom [5] which states that cream is the color of dilution on dark horses and golden fur like in the horse palomino and bucksin. The palomino horses have the color of the mane and the tail are white, while the buckskin has a colorblack on mane, tail and legs. Another example of cream color is cremello and perlino. Cremello horse has pink skin, blue eyes and ivory fur (ivory). Perlino horses have the same color except on the part of the mane and tail that is darker than the color of body hair. Eumelanin and phameomelanin pigments on horses with dominant homozygous CcrCcr will be diluted into ivory colors known as cremello and perlino colors. This cream gene is mostly found, but not all horsepower has this gene. Cream gene is a dominant trait that is not optimal. Horses that have the CC gene have perfectly expressed color pigments. horses that have the Ccr gene are a single dilution that produces palomino, buckskin, or smoky black. The red pigment is diluted to gold with cream color on the mane and tail. Horses that have the Ccr Ccr gene are double dilution which produces cremello and perlino colors.

The results showed that variation of facial marks in Samosir regency were stripe $(59,52 \%)$ followed by star $(16,67 \%)$, blaze $(11,90 \%)$, white face $(7,14 \%)$ and Snipe $(4.76 \%)$. This is in line with Nozawa et al. [6] which states that the white pattern on a horse is found in the form of white spots or a white mixed area. White spots may extend over the areas of a mixture of white and colored fur (roan) or may also appear as separate white spots extending or restricted to an area. The color of the horse is thus found on a horse tobiano, overo, leopard spotting or a horse-like plumage pattern. The spotted color pattern (buchi) is affected by the $\mathrm{S}$ locus and the spotted color genotype is white.

Based on the result of recapitulation, the highest horizontal color in Karo Regency, Humbang Hasundutan, North Tapunuli and Samosir, was found in red chocolate of $27.86 \%$, while the lowest was gray at $7.14 \%$. And on the average highest strike face marks of $54.95 \%$ in Karo District, Humbang Hasundutan, North Tapunuli and Samosir, while the lowest average blaze of $7.47 \%$.

\section{Conclusions}

The spread of horses in North Sumatera is generally reddish brown body color $(30.48 \%)$ followed by consecutive red black (14.73\%), dark black $(12.23 \%)$, faded brown (10.63\%), white (9.15\%), bright yellow and black chocolate $(7.64 \%)$, and gray $(7.14 \%)$. While the horse's face in North Sumatra is generally strike $54,19 \%$, followed by star $(13,26 \%)$, white face $(11,76 \%)$, snipe $(11,56 \%)$ and blaze $(9,23 \%)$. Advocacy should be conducted to provide information that horses in North Sumatra are maintained as a diversity of horses in North Sumatra and have the potential to be developed and conserved as an effort to improve the welfare of Indonesian society.

\section{References :}

[1] Vogel, C. 1995. Complete Horse Manual. Dorling Kindersley Limited, London.

[2] Edwards, E. H. 1994. The Encyclopedia of The Horse. Dorling Kindersley, London.

[3] Roberts, P. 1994. The Complete Horse. Multimedia Books Publishing, Ltd. London.

[4] Bowling, A. T. \& A. Ruvinsky. 2000. The Genetics of the Horse. CAB International Publishing. London

[5] Eckstrom, E. 2002. Equine Coat Colors and Genetics.http://www. Painted Barr Stables.blogspot.com. [4 Oktober 2010].

[6] Nozawa, K., T. Amano, M. Katsumata, S. Suzuki, T. Nishida, T. Namikawa, H. Martojo, B. Pangestu \& H. Nadjib. 1981. Morphology and Gene Constitution of the Indonesian Horse. The Origin and Phylogeny of Indonesian Native Livestock. Part II (1981): 9-30. 